AVANT, Vol. XII, No. 2

ISSN: 2082-6710 avant.edu.pl/en

DOI: 10.26913/avant.2021.02.05

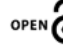

OACCES 2 ing

\title{
Can Arnold Berleant's Aesthetics of Engagement Be Applied to Conceptual Dance?
}

\author{
Lilianna Bieszczad \\ Institute of Philosophy \\ Jagiellonian University \\ lilianna.bieszczad@uj.edu.pl
}

Received 16 November 2020; accepted 6 December 2021; published 28 December 2021.

\begin{abstract}
The central aim of the article is to reflect on whether-and if so, how-Arnold Berleant's theory of aesthetic engagement can be applied to works described with the controversial term 'conceptual dance', in other words, to works that undermine the determinants of a dance performance. Berleant stresses the open nature of his project of aesthetic experience; however, he does not describe works that seek to destabilize perception in dance performances. With this in mind, the concepts of aesthetics and critical aesthetics are considered as indicating a possible direction for the further development of the ideas outlined in Berleant's Sense and Sensibility. This extension of Berleant's thought enables the problem of destabilization of perception to be grasped, and encompasses the issues of criticality and the political, which animate the performances of Xavier Le Roy, Jan Ritsema and Jonathan Burrows.
\end{abstract}

Keywords: Arnold Berleant; aesthetics of engagement; aesthetic experience; Xavier Re Loy; Jan Ritsema; Jonathan Burrows

\section{Experience as engaged participation}

When Arnold Berleant proposed reforming Immanuel Kant's aesthetics, his critical arguments were to some extent based on examples from contemporary art. Berleant's aesthetic theory is centered on engaged participation and assigns value to the body and senses in aesthetic evaluation (1991, 2004, 2010a). This proposal seems to have been particularly suited to the field of dance theory, where it became known as 'performative aesthetics', in the sense in which Anna Zeidler-Janiszewska used this term: as a symbol of the transition from the aesthetics of the object to process-orientated aesthetics $(2007$, p. 87). Berleant criticizes the universalist aspi- 
rations of Immanuel Kant's aesthetic philosophy, along with its dualist distinctions and separations, and asserts that the notion of aesthetic engagement fits perfectly not only with the performing arts, but also - and this may at first sight seem controversial — with traditional, non-performative arts (Berleant, 1991, p. 5).

In this article, I would like to consider whether Berleant's aesthetics of engagement is sufficiently robust and flexible to encompass all possible art forms, and whether it is capable of dealing with the wide variety of dance forms that have emerged, especially in the twentieth and twenty-first centuries; thus not only classical dance forms, but also those controversial dance works that undermine all the basic conditions that allow them to be recognized as art. These are important issues because, firstly, Berleant understands experience in a specific way, framing it in terms of interactions or transactions, following John Dewey (Dewey, Benthley, 2018) and therefore in opposition to the dualistic distinction between subject and object. Hence, he stresses that experience is a process of mutual interaction, and of being subjected to influence ${ }^{1}$, thereby opposing the subjectification of experience and stressing its unifying character, through integrating various factors from the aesthetic field (a theoretical construct outlined in his first book, The Aesthetic Field) (1970, 2004, p. 43, 2010b, p. 10). Then, secondly, in suggesting that art should be approached from the perspective of the experience of art (1991, pp. 3-6), Berleant does not refer to pure facts, since he argues there is no such thing as pure experience ${ }^{2}$. Neither does he have a theory that provides a basis for the formulation of objective knowledge, due to his conception of interaction. Thus, his perspective is non-dualistic: he calls it the aesthetics of context and continuum (Berleant, 2004, p. 22, 23). Therefore, the question remains as to whether-and if so, how-experience ${ }^{3}$ thus conceived can encompass controversial works occupying positions at the borders of art, which are aimed at destabilizing the viewer's perceptual process. Intentions such as these can be observed in 'conceptual dance', or in works in which movement - hitherto the basic determinant of dance-is abandoned, thus disrupting the prevailing conditions that allow a dance spectacle to be viewed as such. At this point, I must stress that the fundamental aim of this text is not to consider whether Berleant's aesthetics projects actually consider such controversial works, even if the author clearly declares his openness to such considerations. The aim is rather to explore how his research proposal can be developed as a tool for the investigation of subversive works. It goes without saying that the conceptual instruments of traditional aesthetics developed thus far are not sufficient for capturing the phenomena described as 'new choreography' or 'new dance'.

\footnotetext{
${ }^{1}$ Berleant is indebted to Dewey for this conception of experience, and although he rejects Dewey's biological approach, Berleant clearly acknowledges these inspirations and draws inspiration from pragmatism (Berleant, 1991, p. 17). On the oversimplified approach to Dewey as a representative of biological reductionism, see: Wilkoszewska, 2003.

${ }^{2}$ It is worth mentioning that Berleant eagerly invokes Husserl and epoche, which seems to suggest that the ideal of phenomenology, that is, of starting from experience, is tempting to him. On this topic, see (Berleant, 2010b, pp. 26-28). But he consistently emphasizes that there is no pure experience, that all experience is culturally, historically and contextually conditioned.

${ }^{3}$ He understands aesthetic experience broadly, taking it to include not only phenomena from the field of art, but also everyday life.
} 
It is not possible to unravel all the threads that are interwoven in such works, but I would argue that it is possible to extend Berleant's theory, through its application to various phenomena emerging in the field of anti-dance, and that this theory can tackle the problems addressed by contemporary dancers/performers, such as engagement, politicality, criticality ${ }^{4}$, etc. In his most recent work, Berleant refers to perceptual politics (2010b, pp. 201-220), and his conception of aesthetics places great emphasis on its critical aspect (2010b, p. 99). Although he does not consider these issues in relation to art, but rather to environmental experience, on the basis of the principle of continuity he has adopted, they can also be translated into this field of human activity, especially as he repeatedly emphasizes the unique capacity of this principle to define perceptual experience more clearly (Berleant, 2010b, p. 8).

\section{Aesthetic theory in Art and Engagement - the aesthetic engagement in dance}

When Berleant formulates the first outline of his aesthetic theory, he emphasizes how important the experience of contemporary art was for him, as it led him to formulate his notion of aesthetic engagement. He cites various examples that primarily serve to confirm his main thesis, i.e., that disinterested contemplation (developed from Kantian and Schopenhauerian aesthetics) does not reflect the complexity of the phenomena of art; that in happenings the inseparability of an object from its surroundings is accentuated; and that increasingly the works of artists require participation and being active, and demand contribution, which he supports with examples of happenings and performance art (Berleant, 1991, pp. 20-49). On this basis, he concludes that aesthetic experience confirms the continuity of art and life rather than their separation, insisting on the process-oriented and incidental nature of art; its contextuality rather than autonomy. At the same time, when he describes the course of such an experience on the basis of examples from various genres, he uses expressions suggesting that, for example, its totalizing character should be considered ${ }^{5}$ (Berleant, 2010a), and he draws attention to its integrative aspect (1991, p. 32-50). When Berleant turns to aesthetic engagement in dance, he writes about its vitality, the viewer's involvement in the event and the intimate relationship with what is happening (because, crucially, it is not an object, or a work of art, but a process, an event taking place) (1991, p. 49). He describes viewers becoming unified with a work, suggesting fulfilled experience, emotional ecstasy, positive valorization, (and recalls the well-known notion from the phenomenology of dance, that one cannot distinguish between the dancer and the dance). This is evident from his continual insistence that aesthetic engagement is a living, vital experience, and his repeated reference to the notions of flowing energy, vitality and even kinesthetic/somatic empathy (1991, p. $168 \mathrm{ff}$.). It is important that the notion of engagement (let us stress that it is somatic, involving all the senses, including the lower ones, memories, etc.) is a response to the concept of distance and disinterested contemplation - taken from the British empiricists, but detectable even in Aristotle - which is how the

\footnotetext{
${ }^{4}$ With regard to the conception of criticality intended here, I refer to I. Rogoff, 2006, p. 11. On the issue of politicality in dance, see. A. Vujanović, 2013, p. 181-191.

${ }^{5}$ However, he does not mean the 'unity of form' that appears in Dewey, but rather what Dewey calls 'total seizure', 2010a, p. 67.
} 
experience of art is conceived in traditional aesthetics. Berleant tries to undermine this, precisely by emphasizing proximity to the work/event $(1991, \text { p. } 44,45)^{6}$.

In my view, the emphasis on vitality can lead to misinterpretations of Berleant's theory, giving the impression that when focused on dance he only takes into account the active, bodily sensation of the dancer's movements, full of energy and vigor, thereby favoring legitimized dance art forms. This preference excludes works based on stillness, which André Lepecki, for example, describes as being accused of betraying the essence of dance (2006, p. 1, 2).

It is worth mentioning, however, that in Art and Engagement Berleant evokes various modalities of dance, not only ballet or modern dance, but also postmodern dance, such as that of Yvonne Rainer. Although he cites the examples of Merce Cunningham or Vito Acconci, he does not describe in detail the specificity of their works, limiting himself to casual remarks to the effect that they introduce everyday movement into art (1991, p. 41).

\section{Performative dance—conceptual or 'just' performance?}

Let me cite examples of artists associated with 'conceptual dance', because they are likely to be the target of the doubts that have been mentioned in the previous sections. It is worth mentioning that, when considering dance, it is not possible to transfer the meanings of terms commonly used to describe other arts, and not only the visual arts; for example, this applies to postmodern dance or particularly conceptual dance. According to the performance maker and theorist Bojana Cvejič, when the term conceptual dance is assigned to this type of activity, it causes unnecessary confusion. In the panel discussion entitled "Not conceptual" (quoted in: Fabius, 2012) (led by Jonathan Burrows with Jérôme Bel and Xavier Le Roy), it was argued that conceptualism tends to be associated with excessive theorizing, and therefore with a strong separation between what is thought and what is felt, between what is dance and what is not; with prioritizing the mind and reducing dancers' actions to a passive reproduction of the choreographer's ideas - this is one of the reasons why artists request that this term not be used. Yet the works of such artists are "highly performative"; they constitute a conceptualization of the criteria of dance, rather than its negation as a practice of the body. In an attempt to describe the relationship between conceptualism in the visual arts and dance, Cvejič lists some similarities between them, such as: self-reflection, criticism of institutions and the art market, and a rejection of the monopoly of art-dealers and intellectuals who claim the right to determine what is dance and what is not (2006, p. 49-58).

There is a lack of consensus and conflicting opinions among the theorists with regard to how the work of such artists should be described, given that the artists themselves reject the term 'conceptual'. Nevertheless, there are discussions on this issue (e.g., Is there such a thing as

\footnotetext{
${ }^{6}$ The problem of the viewer's intimate contact with a work arises due to the fact that Berleant does not have a conception of a strong, subjective subject, because he is close to the position of ecology. Although he uses terms such as 'viewer', 'artist', etc. (following the example of pragmatism, I assume that he considers them to be functional), his main philosophical assumption is that there is continuity between the subject and the object. This results in interpretative difficulties.
} 
conceptual dance?), the term 'conceptual dance' is in circulation, and artists use it themselves (Cvejič, 2006): all this entails that the term still functions in linguistic practice.

In my view, the activities of the aforementioned artists deserve to be described as 'performative works" ${ }^{\text {" }}$. If we consider their specificity and diversity, they can be described as open, denying the boundaries between art forms, engaging in critical practice, self-conscious, and manipulating the process of perception. Cvejič enumerates these characteristics as specific to conceptualism, but I would argue that they are also a feature of performance art, in terms of these most general assumptions. This is due to the fact that in the second half of the twentieth century works straddling the borders of genres are typical. Hence the concept of intermediality, combined with happening (which was introduced by Dick Higgins), also seems to be relevant here. It rather suggests exploring the space of raw, undefined works, which cannot be easily located within the world of art, or cannot be pigeonholed in a particular genre that matches precisely to conceptual dance. (However, in the manifesto of conceptualism, attention is drawn to the concept as material for works). Perhaps Marco De Marinis is correct to write about performative dance rather than conceptual dance when dealing with Jérôme Bell's works, which are also referred to with terms such as 'non-dance', 'a-dance' etc. $(2013, \text { p. } 145)^{8}$.

Conceptual dance, like performance, due to its evident critical strategies, aims to overturn conceptual boundaries. It is often politically determined. As Cvejič writes, it falls into the paradox that, although it has its origins in the criticism of institutions, it also functions within them by exposing or dismantling ideologies (2006). It is supposed to be "in-between", to perform and to break down genre or media distinctions, resisting attempts to name. This is how RoseLee Goldberg conceives it (2011, pp. 141). André Lepecki also thinks that a distinguishing feature of such artists is their lack of interest in the dance label $(2004, \text { p. 174) })^{9}$. When Goldberg refers to dance, he draws attention to those works of artists from various fields who cooperate with each other; dancers, artists and musicians, and thus works that are difficult to class as dance or a happening, dance or non-dance, that blur the boundaries between life and art 2011, p. 141).

It is precisely this aspect, namely that it is "difficult to tell the difference", which has become a conscious strategy of criticism and resistance on the part of dancers, but also an expression of their becoming involved in politics, which the practice of performance art is known for (this can be read "between the lines" of Jonathan Burrows' statement (2018). In Burrows's interpretation, the instability, the constant changeability of works, the fact that it is impossible to determine what kind of spectacle the performance can be classed as-all these factors are elements of artists' opposition to becoming a product (2018, p. 261). According to Burrows, the "performative confrontation of the dancers" (from performing alone, through to collective performance), struggling with superfluity in relation to what is "easy to quantify or to assess or to monetise", is the practice of resistance, "to disturb the comfortable", and is the evasion of "arrangements" (concerning both the relationship between art and institutions, but also

\footnotetext{
${ }^{7}$ In terms of understanding performativity in relation to dance, I refer to Josette Féral's proposal and the distinctive features of performative theatre she mentions. For a more detailed treatment of this issue, see. Féral, 2011.

${ }^{8}$ Marinis refers to the basic determinants of performance that pervade the most recent theatre (similarly to Féral).

${ }^{9}$ Artists deliberately unite, often creating collectives.
} 
allowing oneself to be subject to politically conditioned aesthetic evaluations) (2018, p. 254255). This is the purpose served by performative actions that are "difficult to understand" and "difficult to describe", about which Jeroen Fabius writes in the context of the actions defined by the controversial term 'conceptual dance' (2012). This means that what Burrows described as the "refusal of movement", demonstrated by the dancer and choreographer Erdem Gündüz, known as "The Standing Man" in Istanbul, is the "the opposite of a refusal to engage" (2018, p. 260-263).

In Mark Franko's interpretation, resistance is a "trope within which movement and representation are ambiguously articulated" (2018, p. 9), so in a single gesture dance can embody and oppose the effects of political power, can at the same time encode norms and the deviations from them. Ana Vujanović also describes the agential power of the dancing body in this way (2013). As a result of such thinking, many dance commentators (Franko, 2018, p. 8, Fabius, 2012) focus on "how dance works" to release the agential potential of the Austinian performative, by for instance the performative evasion of rules, norms or canons ${ }^{10}$. Franko describes this as "questioning the lexicons and syntaxes that have effected such constructions in dance" (2018, p. 11).

Among the features typical for conceptual dance, Cvejič lists the self-conscious strategies of artists who destroy borders and disrupt perceptual strategies, often in dialogue with the visual arts. (This is also often identified with the so-called performative turn, as outlined by Erika Fischer-Lichte (2008)). Among the various forms of artistic activity, experimentation with the framework of perception is particularly noteworthy, being based, among other things, on destabilization, dislodging the viewer's habits from the matrices. (I omit detailed analyses of other important determinants - such as self-referentiality, politicality and criticality —of this type of activity, etc.). According to Cvejič, these activities are characterized by "perceptual self-reflection", directed towards performative tools, towards their display conditions, the division of the roles of the spectator-artist and the procedures for their evaluation. I would especially like to focus on this issue, because the problem of perception is also crucial in Berleant's aesthetics.

\section{Xavier Le Roy's Untitled}

The representative works in this respect include Xavier Le Roy's Untitled, in which viewers are confronted with the fact that all the determinants of their interpretation-including those associated with the institutional framework - have been refuted. It is here that the theatrical conventions of traditional aesthetics regarding the division of the roles of viewer-artist, auditorium-stage are denied. At the outset, the viewer is deprived of the naming framework, i.e., the title, which allows the work to be interpreted within the framework of the conventions adopted by the artworld (Cvejič, 2015). This leads to the creation of a space of "sensory deprivation", where the viewer, seated as if in a conventional setting before a black abyss, where nothing can be seen, gets a flashlight, seemingly for fun. Yet it is this flashlight that allows the

\footnotetext{
${ }^{10}$ An important element is that performative strategy is consciously adopted by dancers and choreographers who dance and theorize simultaneously.
} 
viewer to partially expose some dummies that barely move (it is not clear whether they are disguised people or just impersonal puppets). This undermining of the border between the human and non-human is significant, but it does not seem to be the most important aspect of this work. In its entirety, the performance is characterized by the uncertainty of its message. It is not possible to discern exactly what is happening on stage; the stillness or partial movement of the puppets only reinforces the audience's consternation. There are no signs of dance here. The lack of a clearly defined message regarding the artist's expectations with regard to the audience causes impatience and dissatisfaction after around fifteen minutes. The viewers are in a state of doubt - are they supposed to become involved in the work and enter the darkened space, as is expected with performative strategies? They receive no answers to their doubts from the silent stage, where still nothing is happening, thus reversing the usually one-way direction of the stage's relation 'to' the audience. Here, it is not the choreographer, but rather the audience that makes claims on the stage/artist. The main problem for the viewers is therefore that they do not know how to behave. The residual and fragmentary nature of their perception, through the light of the flashlight and the fog which appears later on, the blurred border between the stage and the audience, the dummy crossing this border and coming into the auditorium - all this contributes to confusion and leads to a negative evaluation and dissatisfaction. The artistic work confronts the audience with their own expectations as to what tools they should use to recognize and categorize the performance. Even when, at the end, the puppet enters the auditorium, posing questions and thus indicating its own limited perception, this does not direct the interpretation of the work.

This is not the only thread that Le Roy has problematized in his artistic performative works. Apart from dismantling the dualistic division between the stage and the audience, and the onedirectional message in the relation between the viewer and the artist, he has also addressed the issues of the hybridity of bodies and the extension of the body in the surroundings. Untitled is therefore an example of the "discursive intervention" - to use Rumsey Burt's phrase - of an active, dancing body (2006, p. 18-20).

I have presented only a de-contextualized fragment of a work in which viewers were involved, where their role recalls the essential features of works that seek to shake viewers from their habitual perceptual matrices (an aim typical for performative strategies, e.g., in FischerLichte's description of the experience of being "in-between" (2008). Thus, the audience is separated, on the one hand, from the customary conventions which were the source of the aesthetic satisfaction derived from the simple feeling of empathy with the energy of dancer's body, and also, on the other hand, from the clear message from the artist.

In terms of Berleant's theory, one could argue that, due to the lack of visible dancers as subjects of action (instead of visible movement, the viewers had to deal with largely motionless dummies, only one of which moved its head), in this performance it is not possible to speak of bodily empathy, in which the viewer and the dance become unified, through feeling the energy of the dancers' movements, because the viewer does not even know where such dancers are, or indeed if they are there at all. The stillness or minimal range of the mechanical movements further deepens the viewer's state of disorientation. The introduction of humanoid objects was not without significance, since it further problematized the relationship "between" 
the human and non-human, between the subjective and objective, and between who is watching and who is being watched. At this point, an interesting analogy with Berleant's aesthetics can be drawn, since he also undermines established dualisms and the separations based on them, such as illusion-reality, subject-object.

So can the model outlined in Art and Engagement, focused on body movement, be applied here? Did Berleant, who writes that space and time result from motion, only have a narrow understanding in mind - one reduced to the dancer's actions? Before we return to this question, let us look at a few other examples, which employ similar mechanisms, and which problematize the established dichotomies of thinking-action, theory-practice, mind-body.

\section{Ritsema's and Burrows's Weak Dance Strong Questions}

An excellent example of Ritsema's and Burrows's re-performative re-thinking is provided by the performance Weak Dance Strong Questions, which aims to question itself. According to the declarations of its creators, it is a dance that constantly asks questions, but which does not expect answers. As the dancers claim, it undermines the basic principles associated with improvisation, such as bodily contact, but also puts it in a position "between what has hitherto been the domain of dance practice" and theory. According to Ritsema, the artists danced "questioning everything they did", thereby dismantling the previous determinants of improvisation as synonymous with the essentialist need to express oneself, and thus the hidden universal truth. Ritsema explained the assumptions behind the performance by drawing on Gilles Deleuze's thought (invoking his concept of the body without organs, the body as affect, movement and intensities) (2004), using philosophical discourse to define the role of their bodies in the performance as disciplined, drilled thinking. At the same time, he stripped the dance performance of the widely shared belief that the domain of the (dancing) body is action and not thinking. And although these artists declared that they wanted to reject the theatrical determinants of the performance, the established canonical rules of their evaluation/classification, they also implicitly referred to the politics of the theory accompanying them, its inadequacy and incommensurability.

The assumptions given expression in these works reveal a peculiar parallelism with the views of Berleant, who, while adopting the position of anti-dualism, renounces all of the following: the essentialist subject, the need to express emotions, the idea of the artist expressing themselves through dance, the reduction of the body to the name of an object (proposing, interestingly, in reference to Merleau-Ponty, that it be understood it in terms of a field (2004). Through the principle of continuity, Berleant indicates that the body does not exist without thinking that the body also thinks.

On the other hand, from the notes written by Ritsema to accompany the preparation of the performance TODAYulysses it is clear that the main goal was to blur and destabilize all the existing determinants of a performance, starting with the techniques of creation and decoration, as well as the necessity of expressing aesthetic values, such as beauty or emotion-feeling. According to Ritsema, the spectacle should be a plane open to destabilization, displacement, and decentralization, in order to shake the viewer out of all attitudes, expectations and habits, including aesthetic ones. In this way, the artists create a place, delineating an area "in-between" 
that allows, as they write: "to rethink and reconsider everything" (Ritsema, 2004). It is significant that they thereby also broaden the space of the terms customarily associated with dance performance. In both works, Ritsema states that he is subjecting the determinants of the theatricality of performances to critique and improvisation, but in reality they do much more. They create a kind of a new theoretical-methodological approach, a new language of movement, delineating new areas between the matter of the body and language (as writes Fabius (2012) for whom the analysis of concepts in dance leads to the study of the embodiment of thought).

\section{Aesthetics as a theory of sensitivity}

In his reflections, Berleant does not avoid examples from the field of contemporary art; on the contrary, it is by referring to them that he postulated the expansion of the field of aesthetics and broadening the understanding of art (2004, p. 8-10). He does not analyze these specific cases from the field of dance in detail, but he does refer to minimalism, conceptualism, and performance art. When he wrote, for example, about conceptualism, he paid attention not so much to these works replacing a work of art with a verbal commentary, but rather to the attempt to stir the viewer's imagination. He does not reduce the interpretation of conceptualism to an analytical language of expression, as Joseph Koshut does, but rather points to a new form of communication through visualization. This is because he is against the reduction of art to a merely intellectual message conveyed through cognitive symbols (1991, p. 12, 163).

When Berleant turns to video dance, he highlights the importance of modes of perception that the camera makes it possible to capture; thus, the camera becomes an active participant of the dance, its extension (Berleant, 2016). When discussing the camera, he focuses specifically on filming the movement of bodies. His texts consider the new possibilities for manipulating perception by means of frames and filming, by zooming in and out of perception, by breaking down perception, dislodging habitual matrices. According to Berleant, video dance requires a new kind of perception and a fresh evaluation of artistic creation, since an element of surprise is introduced, with time-lapsed images, sudden slowdowns or accelerations of movement, all of which dislodge the viewer from of the perceptual habits associated with live dance works. Performance now incorporates the possibility of zooming in on the details of the dancer's body, the subliminal activation of kinesthetic feeling in motion, and extending the spectrum of sensations through the perspective of the camera's eye. According to Berleant, there is a communal experience here, because the camera captures from one perspective, for everybody, and changes the parameters of the perception of movement, widening the possibilities of the perception of its space-time continuum. In this description, Berleant still does not renounce empathy with the dancers' body movements, but he demonstrates that perceptual space has been expanded with new technologies. At the same time, he fails to notice the problems associated with the images of moving bodies being processed through media. This problem came to the fore in the context of differences in the perception of live and filmed activities (e.g., with Fischer-Lichte's concept of performance (Duda, 2007, p. 187)).

Berleant touches on the aspect of manipulating perception in art in the context of performance art, conceptual art and dance (2010b, p. 202). He explains that one of the most valuable elements of art is the manipulation of perceptual material itself, since it reveals different ways in 
which experience is shaped and modelled. Berleant points out that such manipulation can also convey meanings. This is consistent with his distinction between sensual elements and meanings in experience (2010b, p. 36).

The concept of perception is of key importance in Berleant's aesthetics, thus he refers to its etymology-Aisthesis, sensual perception ${ }^{11}$. That is why, for example, when he describes theater and refers to empty space, he is writing about perceptual space. At the same time, however, he shows that there is no empty space in perception; it always has some significance (1991, p. 164). One could say that when the viewers are caught up in the trap of experience, in the established norms that determine performance, as in Le Roy's works, the process of perception in the form of engaged participation still takes place (due to a non-dualistic way of thinking, empathy is also understood differently than it is by John Martin (1933, p. 13-16), because perception itself is a movement of interaction. In effect, Berleant also wants to broaden the issue of the perception of works of art, which cannot be limited to a pleasant, holistic integration with them, but rather involves responding actively, stimulating the awareness of the intellect, through the mediation of the body and the senses. I would also understand Berleant's theory in this way, since for him dance performance is a situation requiring interaction, as he writes in Art and Engagement.

However, in order to understand his perspective, one has to go back to the sources of his inspiration, which influence his view of perception as interaction. He is close to the positions of ecology, modern physics, and pragmatism, and it is in connection with these fields that he adopts the central principle of continuity (which does not permit the senses, imagination, intellect or bodily involvement to be separated). With this focus on continuity, therefore, Berleant did not reduce the experience of art to either the reception of an intellectual message or a response of bodily empathy, so he was unable to accept Martin's dualistic conception of empathy. The basic assumption - that there is no interior and exterior, that there exists only a continuum, that there is no subject and no object, no object and no environment; only continuity — entails that the entirety of dance interaction involves a wide range of factors.

In the context of inspiration drawn from ecology, one can understand why the notion of performance in dance tends to denote an event, a situation taking place "now", in specific circumstances. It is worth noting that it also emphasizes the understanding of perceptual experience as active. Berleant introduced the element of activation early on in his work, in Aesthetic Field, with the term 'performative factor', but his conception is different to that of the representatives of performatics, who use the similar term 'performativity'. In this regard, Berleant drew attention to the active attitude of the viewer, describing it with the terms 'activator' and the 'focused factor'. Thus there are performative elements in Berleant's approach to performance, although he himself does not directly refer to the representatives of performance studies. He takes into account the transformative character, the inseparability of the situation from the circumstance in which it happens; he describes engagement as participation in a process, as one of the factors contributing to the happening situation. What matters to him is the atmosphere, the elements

\footnotetext{
${ }^{11}$ However, he does not mean just the sensual character, but as he emphasizes, it covers a wider range of sensations, of a somatic, intellectual, imaginative nature, etc. He also always indicates its cultural conditioning and contextual location.
} 
of the surrounding space, including objects, as with the case of puppets. This is due to the fact there is a continuity that encompasses the subject and the object, the self and the world, the object and the environment, etc. (1992, p. 4). He also has in mind the situation's power of influence, as what is happening, the process. This is reminiscent of Marvin Carlson's description, who, when referring to John Austin's performativity, writes about the strength and power of agency (2004). In this inseparability of effects and results, there seems to be a resemblance to Austin's notion of performativity and the concept of agency (2018).

For Berleant, the point is not that the viewer emotionally identifies with the dancer's actions, rather that even if the viewer reacts negatively, if there is a lack of satisfaction, this is still part of the work, or rather a component of the active experience of performance, which takes place in specific circumstances, "now"12. Therefore, it is of no importance whether or not the viewer reacts positively and is satisfied with the experience. Berleant is not interested in crowning the experience with fulfillment typical of Dewey's real experience. The fact that he criticizes Dewey's concept of formal unity supports this interpretation. In his critique of the pragmatist's position, Berleant emphasizes that there are unfinished works, cites the example of camp, and shows that in art nowadays one must sometimes stop, reflect and consider (Berleant, 2010a, p. 67). Therefore, making an active contribution, participating in the experience of an event, means not only doing so on the emotional level of reacting physically, through empathy with the rhythm of a moving body, but also on the intellectual level, involving the imagination, intuition, etc.

Although ecology requires a holistic approach, in Sense and Sensibility Berleant makes clear that he also distrusts the concept of the whole (2010b, p. 11), in spite of the fact he often employs it himself. His attitude can also be explained through reference to the perspective of pragmatism (Berleant wrote his $\mathrm{PhD}$ thesis on Dewey), in which functional distinctions are adopted, instead of ontological ones (Berleant writes about perceptual ontology). The notions of integration or the whole that he uses are functional, but do not assume a homogeneous unity; instead, they rather explain, in a useful way, the very process of interaction occurring in experience, based rather on co-presence, cooperation, involvement in the active process of the creation and reception of meanings created through the atmosphere of an ongoing situation. Involved in this process are the elements of space and objects, which create an energetic and perhaps sometimes uncomfortable situation of integration with concrete actions and circumstances.

It is also significant that in later works Berleant introduces the concept of negative aesthetics, incorporating it into criticism (2010b, 163-181). Admittedly, he does not describe this concept in the context of art, but in the context of aesthetics. Nevertheless, of crucial importance seems to be the notion of critical aesthetics, which sharpens perception and aesthetic meaning, critically demystifying the political determinants hidden behind traditional aesthetics embodied in the artist's message. This can be applied to the above-mentioned examples of artistic works.

\footnotetext{
${ }^{12}$ Berleant suggests abandoning the issues of emotion, expression or representation, which fragment the world into viewer, artist and work of art. (2007).
} 


\section{Conclusion}

In his declarations, Berleant argued that it is the privilege of the contemporary artist to challenge the aesthetician, to astonish, to challenge conventions and increase the possibilities of experience (2010, p. 69). He showed that the point of aesthetics is to capture that which eludes constraints, conceptualizations, etc. He saw "the various moral bonds that link art to its social context" (2004, p. X). Generally speaking, he stressed the processes that are occurring, rather than the object-work of art, extending what is aesthetic "to areas of action and practice where until now these concepts were considered peripheral and inappropriate" (2004, s. X).

It is worth remembering these assumptions, which are necessary to understand the great capacity not only of the formula of participatory engagement, but of environmental aesthetics in general. Because although Berleant did not analyze examples in detail, i.e., conceptual dance, this does not mean that he did not appreciate such art forms. In his later work (2010c), Berleant considers political themes, focuses on social implications, and highlights its critical potential. These are categories that he does not refer to in the context of dance, but they are present in his project in the concept of aesthetic experience ${ }^{13}$, which goes beyond the field of art. This is an advantage of his thought, in that it grapples with everyday life, and thus environmental issues; therefore, the conclusions drawn from his conception of aesthetics can also be suitable for the art of dance. It is precisely such issues, i.e., those of perceptual politics (2010b, p. 201 220 ) and being critical, that are now especially relevant in dance, as evidenced by the excellent selection of Marta Keil's texts (2018).

\section{Bibliography}

Austin, J.L. (2018). How to Do Things with Words (1962). J.O Urmson (ed.). Martino Fine Books.

Berleant, A. (1970). The Aesthetic Field. A Phenomenology of Aesthetic Experience. 1 ed., Springfield: Charles C. Thomas.

Berleant, A. (1991). Art and Engagement. Philadelphia: Temple University Press.

Berleant, A. (1992). The Aesthetics of Environment. Philadelphia: Temple University Press.

Berleant, A. (2004). Re-Thinking Aesthetics. Rogue Essays on Aesthetics and Arts. New York: Routledge.

Berleant, A. (2010a). Zajmujący Dewey: Spuścizna Deweyowskiej estetyki, (Engaging DeweyThe Legacy of Dewey's Aesthetics), Sztuka i Filozofia, (37) 59-70.

Berleant, A. (2010b). Sense and Sensibility. Aesthetic Transformation of the Human World, St. Adrews Studies in Philosophy and Public Affairs 6, Exeter Eng.: Imprint Academic.

\footnotetext{
${ }^{13}$ It should also be remembered that he believes that there is continuity, and therefore he did not sharply distinguish the experience of art from other experiences of a cognitive and religious nature, or art from everyday life activities.
} 
Berleant, A. (2016). Aesthetic Engagement in Video Dance (unpublished lecture). Engagement: Symposium of Philosophy and Dance, Texas State University San Marcos, Texas (8-10 September).

Burrows, J. (2018). Politics, In: S. Ellis, H. Blades, CH. Waelde (ed.). A World of Muscle, Bone and Organs. Research and Scholarship in Dance (252-266), Center for Dance Research, Conventry: Conventry University.

Burt, R. (2006). Judson Dance Theatre. Performative Traces, Abingdon, New York: Routledge.

Carlson, M. (2004). Performance. A Critical Introduction, Routledge: London.

Cvejič, B. Le Roy, X. Siegmund, G. (2006). The End With Judgment by Way of Clarification, In: M. Hochmuth, K. Kruschkova, G. Schollhammer. (ed.) It Takes Place When it Doesn't. On Dance and Performance. Frankfurt: Revolved. https://www.mobileacademy-berlin.com/englisch/2006/texte/cvejic03.html (14.11.21)

Cvejič, B. (2015) Choreographing problems: Expressive Concepts in European Contemporary Dance and Performance, London: Palgrave Macmillan.

Dewey, J., Benthley A.F. (1949). Knowing and the Known, Boston: Beacon Press.

Duda, A. (2007). Estetyka performatywności według Eriki Fischer-Lichte. Teksty drugie, (7) 180192.

Fabius, J. (2012). The Missing History of (non)conceptual dance, In: M. Heering, R. Naber, B. Nieuwboer, E. Wildschut. (red.) Danswetenschap in Nederland, deel 7. Amsterdam: Vereniging voor Dansonderzoek. https://www.academia.edu/4060526/ (22.11.21)

J. Féral, J. (2011), Théorie et Pratique du théatre. Au-dela des limites, edition L’Entretemps, Montpellier.

Fischer-Lichte, E. (2008). The Transformative Powers of Performance. A New Aesthetics. (I. J. Saskya trans.). London-New York: Routledge.

Franko, M. (2006). Dance and the Political: States of Expection. Dance Research Journal, 38(1-2), 3-18.

Goldberg, R. (2011). Performance Art. From Futurism to Present, 3 ed., British Library.

Higgins, D. (1966). Intermedia. Something Else Newsletter, 1 (1).

Keil, M. (ed.), (2018). Choreografia: polityczność (Choreography: Politicality). Warszawa, Poznań, Lublin: Instytut Teatralny im. Raszewskiego.

Lepecki, A. (2004). Concept and Presence. The Contemporary European Dance Scene, In: A. Carter. (red.), Rethinking Dance History. A Reader (p. 170-181). London-New York: Routledge.

Lepecki, A. (2006). Exhausting Dance. Performance and the Politics of Movement. New York and London: Routledge.

Lepecki., A. (2012) (red.). Dance. (Documents of Contemporary Art series), Whitechapel Gallery. 
De Marinis, M. (2013). Performans i teatr. Od aktora do performera i z powrotem. p. 8-40 (E. Bal trans.), In: E. Bal, W. Światkowska. (red.). Performans, performatywność, performer. Próby definicji i analizy krytyczne. Krakow, Poland: Wydawnictwo UJ. https://ruj.uj.edu.pl/xmlui/bitstream/handle/item/150002/ (11.11.21).

Martin, J. (1933). The Modern Dance. New York: A.S. Barnes.

Rogoff, I. (2006). Smuggling: An Embodied Criticality. Transversal. (8).

Ritsema, J. (2004). A Lecture on Improvisation, lecture presented in Arnheim (6.10.2004), in program Dance Unlimited. https://sarma.be/doc/807 (23.11.21)

Wilkoszewska, K. (2003). Sztuka jako rytm życia. Rekonstrukcja filozofii sztuki Johna Deweya. 2 ed. Kraków: Universitas.

Vujanović, A. (2013). Notes on Politicality of Contemporary Dances, In: G. Siegmund, S. Hölscher (ed.), Dance, Politics and Co-immunity. Thinking Resistances. Current Perspectives on Politics and Communities in the Arts. Zurych-Berlin: Diaphanes AG.

Zeidler-Janiszewska, A. (2007) Perspektywy performatywizmu. Teksty Drugie. (5).

Lilianna Bieszczad has a PhD in philosophy, is an adjunct professor at the Department of Aesthetics at the Jagiellonian University Institute of Philosophy, an editor of 'Polish Society of Aesthetics Journal', the editor in chief of an academic journal 'Aesthetics: Journal'. She is the founder of Somaesthetics Unit in John Dewey Research Center at the Faculty of Philosophy of the Jagiellonian University in Cracow. She is the author of the book The Crisis of the Notion of Art. Th.W. Adorno's, H.G. Gadamer's and A.C. Danto's Philosophical-Aesthetical Conceptions (UJ, Kraków 2003), the editor of The Age of Avant-Garde (Universitas, Kraków 2006), The of performative turn in Aesthetics (Libron, Kraków 2013), Practising Aesthetics (Libron 2015), and an issue of 'Modern Culture' journal subtitled 'A Dancing Body' (3(69)2011). Her main fields of interests include modern aesthetics, the postmodern philosophy of culture and the theory of avant-garde. She is also studies the philosophy of dance, somatic issues and performativism. 